\title{
Characterization and Identification of Pawpaw Cultivars and Advanced Selections by Simple Sequence Repeat Markers
}

\author{
Kirk W. Pomper ${ }^{1,2}$, Jeremiah D. Lowe, Li Lu, Sheri B. Crabtree, and Shandeep Dutta \\ Land Grant Program, Kentucky State University, Atwood Research Facility, Frankfort, \\ KY 40601-2355 \\ Kyle Schneider and James Tidwell \\ Division of Aquaculture, Aquaculture Research Center, 103 Athletics Road, Kentucky State \\ University, Frankfort, KY 40601
}

\begin{abstract}
AdDITIONAL INDEX wORDS. kentucky banana, SSR, DNA fingerprinting, Asimina triloba
Abstract. Pawpaw [Asimina triloba (L.) Dunal.], a tree fruit native to eastern North America, is in the beginning stages of commercialization. Cultivars available in the early 20th century have been lost, and significant genetic erosion may have occurred. Polymorphic microsatellite marker loci were developed from enriched genomic libraries. Five marker loci were used to fingerprint 28 cultivars and 13 selections. For the 41 genotypes, 102 alleles were amplified and major allele frequency (0.16-0.94), number of genotypes (2-27), and allele size (144-343 bp) varied greatly by locus. Four loci were highly polymorphic, as indicated by values for expected heterozygosity $\left(\mathrm{H}_{\mathrm{e}}\right)$, observed heterozygosity $\left(\mathrm{H}_{0}\right)$, and polymorphism information content, but only two alleles were detected at locus Pp-C104. A high level of genetic diversity was observed in the studied genotypes. $T^{2} H_{o}(0.68)$ and $H_{e}(0.70)$ were similar and indicated few null alleles. In the 41 genotypes, 39 unique fingerprints were observed. These new microsatellite marker loci will be useful for cultivar fingerprinting, management of collections, and investigation of genetic diversity in collections and wild populations. Grouping of genotypes in an unweighted pair group method with arithmetic mean dendrogram was generally consistent with their origins.
\end{abstract}

The North American pawpaw is a tree fruit in the initial stages of commercial production (Pomper and Layne, 2005; Pomper et al., 2008a, 2008b). The fruit reach up to $1 \mathrm{~kg}$, and are the largest edible fruit native to the United States (Darrow, 1975). Pawpaw has great potential for the processing market (Duffrin and Pomper, 2006; Templeton et al., 2003), as well as fresh market sales at farmers' markets, on-farm sales, and community-supported agriculture (Pomper and Layne, 2005). The fruit is very nutritious (Peterson et al., 1982); it has a unique aroma, smooth custard-like texture, and flavors similar to a combination of banana (Musa acuminate Colla.), mango (Mangifera indica L.), and pineapple [Ananas comosus (L.) Merr.] (Duffrin and Pomper, 2006; Layne, 1996; Shiota, 1991). In addition to the pawpaw's promise as a new fruit crop, there are natural compounds (annonaceous acetogenins) in the leaf, bark, and twig tissues that possess insecticidal and anticancer properties (McLaughlin, 2008).

The pawpaw is diploid [ $2 \mathrm{n}=2 \mathrm{x}=18$ (Bowden, 1948; Kral, 1960)] and the flowers are strongly protogynous, as well as likely self-incompatible (Willson and Schemske, 1980). Pawpaw flowers are pollinated by flies and beetles (Faegri and van der Piji, 1971). Native pawpaw patches can be found in mesic hardwood forests growing in large patches as understory trees and can be found in 26 states in the eastern United States, ranging from northern Florida to southern Ontario, Canada, and as far west as eastern Nebraska (Callaway, 1990, 1993; Kral,

Received for publication 23 Oct. 2009. Accepted for publication 8 Mar. 2010. ${ }^{1}$ Curator, U.S. Department of Agriculture National Clonal Germplasm Repository for Asimina species as a Satellite of the Corvallis, OR, National Clonal Germplasm Repository 40601

${ }^{2}$ Corresponding author. E-mail: kirk.pomper@kysu.edu.
1960; Young and Yavitt, 1987). Usually, few fruit are produced in pawpaw patches.

Pollinator limitation has often been suggested as an explanation for low fruit set in wild patches (Willson and Schemske, 1980). However, low light levels in the forest understory may also limit flower bud formation in summer. If flowers are formed and successfully pollinated, low light levels may also reduce photosynthate partitioning to fruit and reduce fruit set. Pawpaw often produce many root suckers, presumably forming large clonal patches, thus contributing to poor fruit set within a patch due to self-incompatibility. If fruit is produced, the relatively large pawpaw seeds are well-adapted for dispersal by mammals such as coyotes and raccoons (Cypher and Cypher, 1999). Seed germination rates may be low in the wild due to desiccation sensitivity of the seed (Geneve et al., 2003) and because pawpaw seed is killed at freezing temperatures (Pomper et al., 2000).

Clonality is an adaptation of reproduction by asexual means of root suckers by pawpaw to persist and spread on the forest floor. Because this species often reproduces by asexual means and fruit set is usually low in pawpaw patches, withinpopulation genetic variation could be low. However, Pomper et al. (2009b) examined clonality of six pawpaw patches in Kentucky using inter simple sequence repeat (ISSR) DNA markers and found that at least $50 \%$ of the patches were not clonal and had at least two genotypes per patch. Pawpaw is an outcrossing species. Reproduction by seed allows genetic recombination and appears to have played an important role in climatic adaptation in this species. Species whose populations are distributed over a wide geographic region, such as A. triloba, also may maintain significant variation among populations 
(Hamrick and Godt, 1989). In the southern portion of its native range, the distribution of $A$. triloba overlaps that of some subtropical Asimina Adans. species, and some introgression may have occurred.

From 1900 to 1950 , over 50 pawpaw cultivars were selected and named, of which only two remain: 'Sweet Alice' and 'Middletown' (Peterson, 1991, 2003). The rest appear to have been lost through neglect or abandonment of collections, or cannot be identified due to loss of records. Since 1950, additional pawpaw cultivars have been selected from the wild or developed as a result of breeding efforts of hobbyists (Peterson, 1986, 1991). Currently, over 45 cultivars are available from nurseries (Pomper et al., 2009a), and many of these selections are maintained at the Kentucky State University (KSU) National Clonal Germplasm Repository (NCGR) for Asimina species in Frankfort, KY, which is a satellite site of the NCGR in Corvallis, OR. The loss of cultivars over the past century may represent considerable genetic erosion (Huang et al., 1997; Peterson, 1991).

Pawpaw is in the early stages of domestication. Maintaining a high level of genetic diversity is important for the long-term genetic improvement of the crop, and in minimizing vulnerability to disease. A range of molecular marker systems has been used in attempts to evaluate genetic diversity in pawpaw. These marker systems include the minisatellite probe (Rogstad et al., 1991), allozymes (Huang et al., 1997, 1998), random amplified polymorphic DNA [RAPD (Huang et al., 2000, 2003)], ISSRs (Pomper et al., 2003), and amplified fragment length polymorphism [AFLP (Wang et al., 2005)]. Overall, these studies determined that the genetic variation in cultivated and wild pawpaw is similar to those of other long-lived, temperate woody perennials characterized by a widespread geographic range, insect-pollinated outcrossing breeding systems, secondary asexual reproduction, and animal-dispersed seed.

Microsatellites, or simple sequence repeats (SSRs), are a marker of choice for genetic diversity estimates, genetic mapping, and DNA fingerprinting (Wünsch and Hormaza, 2002). SSRs are short (1-6 bp) tandem repeat DNA sequences flanked by unique, conserved DNA sequences. The relative random distribution of microsatellites in the genome, codominant inheritance, high level of reproducibility, and transportability
Table 1. Genetic background of pawpaw selections included in the genetic study.

\begin{tabular}{|c|c|}
\hline Clone & Genetic background \\
\hline $1-23^{Z}$ & Open-pollinated seedling of 'Taylor' \\
\hline $1-68$ & Open-pollinated seedling from 'Overleese' \\
\hline $2-10$ & Open-pollinated seedling of BEF- $30^{\mathrm{y}}$ \\
\hline $2-54$ & Open-pollinated seedling of GAZ-VA ${ }^{\mathrm{x}}$ \\
\hline $3-11$ & Open-pollinated seedling of BEF-33 \\
\hline $3-21$ & Open-pollinated seedling of BEF-43 \\
\hline $5-5$ & Open-pollinated seedling of BEF-54 \\
\hline $7-90$ & Open-pollinated seedling of RS- $2^{\mathrm{w}}$ \\
\hline $8-20$ & Open-pollinated seedlings of 'Sunflower' \\
\hline $9-47$ & Open-pollinated seedling of BEF-49 \\
\hline $9-58$ & Open-pollinated seedling of BEF-50 \\
\hline $10-35$ & Open-pollinated seedling of BEF-49 \\
\hline $11-13$ & Open-pollinated seedling of BEF-53 \\
\hline 'BH10’ & Wild seedling from Cecilia, KY \\
\hline 'Cales Creek' & Wild seedling from Summers County, WV \\
\hline 'Davis' & Wild seedling from Eaton Rapids, MI \\
\hline 'Greenriver Belle' & Wild seedling from Hart County, KY \\
\hline 'IXL' & $\begin{array}{l}\text { Seedling of 'Overleese' female } \times \text { 'Davis' male selected } \\
\text { in Eaton Rapids, MI. }\end{array}$ \\
\hline 'M. Gordon’ & Wild seedling from Cranbury, NJ \\
\hline 'Middletown' & Wild seedling from Middletown, $\mathrm{OH}$ \\
\hline 'Mitchell' & Wild seedling from Iuka, IL \\
\hline 'NC-1’' & 'Davis' female $\times$ 'Overleese' male \\
\hline 'Overleese’ & Cultivated (open-pollinated) seedling from Rushville, IN \\
\hline 'PA-Golden \#1' & Second-generation seedling from G.A. Zimmerman collection \\
\hline 'PA-Golden \#3' & Second-generation seedling from G.A. Zimmerman collection \\
\hline 'PA-Golden \#4' & Second-generation seedling from G.A. Zimmerman collection \\
\hline 'Potomac' & Open-pollinated seedling of BEF-53 \\
\hline 'Prolific’ & Seedling from Eaton Rapids, MI \\
\hline 'Rappahannock’ & Open-pollinated seedling of BEF-30 \\
\hline 'Rebecca's Gold' & Seedling from Eaton Rapids, MI \\
\hline SAA-Zimmerman & Seedling from G.A. Zimmerman collection selected in Amherst, NY \\
\hline 'Shenandoah’ & Open-pollinated seedling of 'Overleese' \\
\hline ‘Sue’ & Wild seedling from Indiana \\
\hline ‘Sunflower’ & Wild seedling from Chanute, KS \\
\hline ‘Susquehanna’ & Open-pollinated seedling of BEF-53 \\
\hline ‘Sweet Alice’ & Wild seedling from West Virginia \\
\hline 'Taylor’ & Wild seedling from Eaton Rapids, MI \\
\hline ‘Taytwo’ & Wild seedling from Eaton Rapids, MI \\
\hline 'Wabash' & Open-pollinated seeding from BEF- $30^{y}$ \\
\hline ‘Wells’ & Cultivated (open-pollinated) seedlings from Salem, IN \\
\hline ‘Wilson’ & Wild seedling from Cumberland, KY \\
\hline
\end{tabular}

${ }^{2}$ Numbered selections from the PawPaw Foundation orchards; numerous wild selections from the remnant collections of H.A. Allard (Arlington, VA), Blandy Experimental Farm (Boyce, VA), B. Buckman (Farmington, IL), J. Hershey (Dowington, PA), R. Schlaanstine (West Chester, PA), and G.A. Zimmerman (Linglestown, PA), plus some from truly wild trees and some from named cultivars that were assembled by R.N. Peterson and H. Swartz at the University of Maryland Experiment Stations in Keedysville and Queenstown, MD.

${ }^{\mathrm{y}} \mathrm{BEF}=$ Blandy Experimental Farm collection (Boyce, VA); numerous wild seedlings plus portions of G.A. Zimmerman's collection, donated posthumously, and assembled by O.E. White and staff at Boyce, VA, from 1926 to 1955.

${ }^{\mathrm{x}} \mathrm{GAZ}=\mathrm{G}$.A. Zimmerman collection containing most, if not all, of the named cultivars of the time plus numerous wild selections and interspecific hybrids; assembled by G.A. Zimmerman of Linglestown, PA, from 1920 to 1940.

${ }^{\mathrm{w}} \mathrm{RS}=\mathrm{R}$. Schlaanstine collection, material descending from G.A. Zimmerman's collection via J. Hershey; assembled by R. Schlaanstine of West Chester, PA, date uncertain, circa 1960. 
across laboratories make these markers useful for assessing genetic diversity, as well as fingerprinting (Kijas et al., 1995; Wünsch and Hormaza, 2002). SSR marker systems have been developed for a number of fruit species, including hazelnut [Corylus avellana L. (Bassil et al., 2005)], blueberry [Vaccinium corymbosum L. (Boches et al., 2006)], peach [Prunus persica (L.) Batsch (Aranzana et al., 2002)], cherry [Prunus cerasus L. (Cantini et al., 2001)], pear [Pyrus communis L. (Yamamoto et al., 2001)], and apple [Malus sylvestris (L.) Mill. (Hokanson et al., 1998, 2001)].

Our long-term goal is to develop reproducible DNA marker systems that can be used to fingerprint cultivars and assess genetic diversity in the KSU repository collection and across pawpaw's native range. The objectives of this study were to develop microsatellite loci and use them to fingerprint cultivars and assess genetic diversity in the KSU collection. The resulting SSR fingerprints should provide a reproducible means of identifying pawpaw cultivars and for managing germplasm in nurseries and the repository collection.

\section{Materials and Methods}

Plant material. Leaf samples were collected from pawpaw cultivars and PPF advanced selections (Table 1). For most genotypes, dormant cuttings were collected in mid-Mar. 2008 from pawpaw trees located at the KSU-NCGR for Asimina species in Frankfort, KY, were placed in beakers of distilled water, and put under fluorescent room lighting at room temperature $\left(21^{\circ} \mathrm{C}\right)$ to force budbreak and leaf growth. Leaf samples of the pawpaw cultivars Greenriver Belle, Sue, and IXL were obtained from Nolin River Nut Tree Nursery (Upton, KY). Leaf samples were also collected from a seedling cherimoya (Annona cherimola Mill.) tree in the KSU greenhouse; cherimoya is in the same family as pawpaw.

DNA extraction. DNA was extracted from leaves using the DNAMITE Plant Kit (Gel Co., San Francisco). About 1 to $2 \mathrm{~cm}^{2}$ of young leaf tissue was used. DNA concentration and 260/280 nm absorbance ratio were determined with a GeneQuant $^{\mathrm{TM}}$ pro RNA/DNA calculator (GE Healthcare Biosciences, Piscataway, NJ). All samples were stored at $-80{ }^{\circ} \mathrm{C}$ until needed.

MiCROSATELLITE-ENRICHED LIBRARIES AND PRIMER DESIGN. Genetic Identification Services (GIS; Chatsworth, CA) constructed pawpaw genomic libraries from DNA extracted from the cultivar PA-Golden (\#1) that were enriched for dinucleotide repeat GA (library B) and for trinucleotide repeat ATG (library $\mathrm{C}$ ) and AAT (library G). Inserts were sequenced by GIS using the DYEnamic ${ }^{\mathrm{TM}}$ ET Terminator Cycle Sequencing Kit (GE Healthcare Biosciences), followed by electrophoresis on a DNA sequencer (model 377; Applied Biosystems, Foster City, CA). Primers were designed from flanking regions using DesignerPCR (version 1.03; Research Genetics, Huntsville, AL) with the parameters of annealing temperature $60{ }^{\circ} \mathrm{C}$, GC content $50 \%$ and amplicon size of 100 to $350 \mathrm{bp}$. Primer pairs were labeled with FAM and were made by Integrated DNA Technologies (Coralville, IA).

SSR-POLYMERASE CHAIN REACTION (PCR) AMPLIFICATION. The SSR-PCR amplification was performed with GoTaq Flexi DNA polymerase (Promega, Madison, WI). The reactions were set up as follows: $4 \mu \mathrm{L}$ of $5 \times$ colorless GoTaq Flexi buffer, 0.4 $\mu \mathrm{L}$ of $10 \mathrm{~mm}$ dNTPs solution, $2 \mu \mathrm{L}$ of $25 \mathrm{~mm} \mathrm{MgCl}_{2}, 0.3 \mu \mathrm{L}$ of $30 \mu \mathrm{M}$ forward primer (fluorescence labeled with FAM) solution, and $0.3 \mu \mathrm{L}$ of $30 \mu \mathrm{M}$ reverse primer (unlabeled) solution, $0.2 \mu \mathrm{L}$ of 5 units/ $\mu \mathrm{L}$ GoTaq DNA polymerase, $2 \mu \mathrm{L}$ of diluted $1 \mathrm{ng} \cdot \mu \mathrm{L}^{-1}$ pawpaw DNA, and $10.8 \mu \mathrm{L}$ of $\mathrm{ddH}_{2} \mathrm{O}$ to bring the total volume to $20 \mu \mathrm{L}$. Six primers were selected and labeled with FAM for use in this study: Pp-B3, Pp-B103, PpB118, Pp-B129, Pp-C104, and Pp-G119. The PCR amplifications were performed using a thermal cycler (Endurance Series TC-512; Techne, Burlington, NJ). The PCR program consisted of an initial period of $94^{\circ} \mathrm{C}$ for $3 \mathrm{~min}$, followed with 30 cycles of $40 \mathrm{~s}$ denaturation at $94{ }^{\circ} \mathrm{C}, 40 \mathrm{~s}$ annealing at $56^{\circ} \mathrm{C}$, a $30-\mathrm{s}$ extension at $72{ }^{\circ} \mathrm{C}$, and a final extension period of $10 \mathrm{~min}$ at 68 ${ }^{\circ} \mathrm{C}$. The PCR results were then stored at $4{ }^{\circ} \mathrm{C}$ until analysis. Products were separated with ABI 3130 Genetic Analyzer (Applied Biosystems) with GeneScan ${ }^{\mathrm{TM}} 500$ LIZ $^{\mathrm{TM}}$ as an internal size standard. Individuals were genotyped with GeneMapper software (version 4.0; Applied Biosystems). At least two replicate amplifications were subjected to electrophoresis and analysis for each primer set.

Data AnAlysis. PowerMarker, version 3.25 (Liu and Muse, 2005), was used to calculate the major allele frequency, number of genotypes, observed number of alleles $\left(n_{A}\right)$, observed
Table 2. Characterization of five new microsatellite loci in pawpaw.

\begin{tabular}{llcc}
\hline Locus & \multicolumn{1}{c}{ Primer sequence } & Motif & $\begin{array}{c}\text { Allele scoring } \\
\text { quality }\end{array}$ \\
\hline Pp-B3 & $\begin{array}{l}\text { Forward: AGCGAAAACGAACATACCTC } \\
\text { Reverse: CCTCCTCCACCACCACTAC } \\
\text { Pp-B103 }\end{array}$ & $\begin{array}{l}\text { Forward: ATGCCCCAACAGAGACTTC } \\
\text { Reverse: GGATGAGACACTCGGCTTAC }\end{array}$ & good \\
& $\begin{array}{l}\text { Forward: ACACCAGCCATGATTATGATTC } \\
\text { Pp-B129 }\end{array}$ & $(\mathrm{GA})_{23}$ & good \\
Pp-C104 & $\begin{array}{l}\text { Foverse: TCCTTCTCACTCCATCAACAAC } \\
\text { Reverse: CAGGAGCCTTACAGGATCAG }\end{array}$ & good \\
Pp-G119 & $\begin{array}{l}\text { Forward: AAACCGTAGTAAAACCAGACAA } \\
\text { Reverse: GGATAGGAAAACATGGTGATTA }\end{array}$ & (AAT $)_{11}$ & good \\
& & & good \\
\hline
\end{tabular}

Table 3. Major allele frequency, number of genotypes, observed number of alleles, allele size, expected heterozygosity $\left(\mathrm{H}_{\mathrm{e}}\right)$, observed heterozygosity $\left(\mathrm{H}_{\mathrm{o}}\right)$, polymorphism information content (PIC), and frequency of null alleles ( $\mathrm{r}$ ) for all cultivars and advanced selections.

\begin{tabular}{lccrrrrrr}
\hline Locus & $\begin{array}{c}\text { Major allele } \\
\text { frequency }\end{array}$ & $\begin{array}{c}\text { Genotypes } \\
\text { (no.) }\end{array}$ & $\begin{array}{c}\text { Alleles } \\
\text { (no.) }\end{array}$ & $\begin{array}{c}\text { Allele } \\
\text { size (bp) }\end{array}$ & $\mathrm{H}_{\mathrm{e}}$ & $\mathrm{H}_{\mathrm{o}}$ & PIC & \multicolumn{1}{c}{$\mathrm{r}$} \\
\hline Pp-B3 & 0.26 & 22 & 9.0 & $175-195$ & 0.83 & 0.78 & 0.81 & 0.03 \\
Pp-B103 & 0.16 & 35 & 27.0 & $252-343$ & 0.93 & 0.90 & 0.92 & 0.02 \\
Pp-B129 & 0.20 & 28 & 15.0 & $166-193$ & 0.88 & 0.78 & 0.87 & 0.05 \\
Pp-C104 & 0.94 & 2 & 2.0 & 175,184 & 0.11 & 0.12 & 0.11 & -0.01 \\
Pp-G119 & 0.35 & 15 & 7.0 & $144-176$ & 0.75 & 0.83 & 0.71 & -0.05 \\
Mean & 0.38 & 20 & 12.0 & $144-343$ & 0.70 & 0.68 & 0.68 & 0.01 \\
\hline
\end{tabular}


heterozygosity $\left(\mathrm{H}_{\mathrm{o}}\right)$, expected heterozygosity $\left(\mathrm{H}_{\mathrm{e}}\right)$, and polymorphism information content (PIC) for all accessions. The major allele frequency is the frequency of the most common allele. The $\mathrm{H}_{\mathrm{o}}$ was calculated as the number of heterozygous genotypes at a given locus divided by the number of genotypes present at the locus. Gene diversity was defined as the probability that two randomly chosen alleles from the population are different. PIC was an estimate that the parental origin of an allele can be determined from the marker locus genotype in any given offspring. The equation for $\mathrm{H}_{\mathrm{o}}, \mathrm{H}_{\mathrm{e}}$, and PIC are given in the PowerMarker software manual. Genetic distance (D) between genotypes was computed as (1 - proportion of shared alleles) (Bowcock et al., 1994). The frequency of null alleles was calculated as $\mathrm{r}=\left(\mathrm{H}_{\mathrm{e}}-\mathrm{H}_{\mathrm{o}}\right) /\left(1+\mathrm{H}_{\mathrm{e}}\right)$ (Botstein et al., 1980). The distance data were used to generate an unweighted pair group method with arithmetic mean (UPGMA) dendrogram.

\section{Results}

Initial sequencing of 34 inserts from libraries enriched for the dinucleotide repeat GA, and for trinucleotide repeats ATG and AAT motifs, led to the development of a number of promising primer sets. After initial screens, six primer sets showed great promise for fingerprinting and genetic diversity studies in pawpaw cultivars (Table 2). The loci Pp-B3, Pp-B103, Pp-B118, Pp-B129, Pp-C104, and Pp-G119 yielded products; however, the locus Pp-B118 was not used in the genetic analysis because of difficulties in determining allele size due to split peaks.

For the 41 genotypes, 102 alleles were amplified (Table 3). Major allele frequency (0.16-0.94), number of genotypes (2-27), and allele size (144-343 bp) varied greatly by locus. Four loci were highly polymorphic, as indicated by values for $\mathrm{H}_{\mathrm{e}}, \mathrm{H}_{\mathrm{o}}$, and PIC, but locus Pp-C104 was nearly monomorphic. $\mathrm{H}_{\mathrm{o}}(0.68)$ and $\mathrm{H}_{\mathrm{e}}(0.70)$ were similar and $\mathrm{r}=0.01$, indicating few null alleles. In the 41 genotypes, 39 unique fingerprints were observed. The pairs 8 through 20 and 'Susquehanna' had the same fingerprint, as did 'Rebecca's Gold' and 'NC-1' (Table 4). An UPGMA dendrogram (Fig. 1), which depicts the genetic relationships among the cultivars and advanced selections, showed five groups. 'Taylor' and 'Wilson' (Group I) were close to each other, but distant from all other accessions. The other four groups are designated by the name of a member: 'Susquehanna' (Group
Table 4. Allelic fingerprints of five microsatellite loci for the 28 pawpaw cultivars and 13 advanced

\begin{tabular}{|c|c|c|c|c|c|}
\hline \multirow[b]{2}{*}{ Genotype } & \multicolumn{5}{|c|}{ Allele size (bp) for each locus } \\
\hline & Pp-B3 & Pp-B103 & Pp-B129 & $\mathrm{Pp}-\mathrm{C} 104$ & Pp-G119 \\
\hline $10-35$ & $183 / 191$ & $266 / 339$ & $166 / 172$ & 184 & $158 / 164$ \\
\hline $11-13$ & 191 & $264 / 305$ & $166 / 172$ & 184 & 158 \\
\hline $1-23$ & $185 / 189$ & $290 / 310$ & 158 & 184 & $158 / 176$ \\
\hline $1-68$ & $185 / 187$ & $268 / 341$ & $158 / 179$ & $175 / 184$ & $158 / 164$ \\
\hline $2-10$ & 191 & $264 / 270$ & $170 / 172$ & 184 & $161 / 164$ \\
\hline $2-54$ & 191 & $264 / 270$ & $162 / 166$ & 184 & 161 \\
\hline $3-11$ & 191 & $272 / 288$ & $158 / 172$ & 184 & $158 / 161$ \\
\hline $3-21$ & $189 / 191$ & $266 / 305$ & $166 / 170$ & 184 & $161 / 164$ \\
\hline $5-5$ & $183 / 189$ & $270 / 305$ & $166 / 168$ & 184 & 161 \\
\hline $7-90$ & $185 / 191$ & $305 / 342$ & $170 / 176$ & 184 & $161 / 164$ \\
\hline $8-20$ & $189 / 191$ & $264 / 270$ & 162 & 184 & $158 / 167$ \\
\hline $9-47$ & 183 & $272 / 274$ & $158 / 166$ & 184 & $158 / 161$ \\
\hline $9-58$ & $183 / 191$ & $264 / 339$ & $170 / 176$ & 184 & $158 / 164$ \\
\hline 'BH10' & 189 & $319 / 321$ & $162 / 170$ & 184 & $144 / 161$ \\
\hline Cales Creek' & $175 / 183$ & $266 / 274$ & $156 / 158$ & 184 & $158 / 164$ \\
\hline 'Davis' & $185 / 189$ & $264 / 268$ & $158 / 164$ & $175 / 184$ & $158 / 164$ \\
\hline Greenriver Belle' & $183 / 189$ & $264 / 266$ & $162 / 172$ & 184 & $158 / 161$ \\
\hline IXL' & $187 / 189$ & $274 / 309$ & $158 / 162$ & $175 / 184$ & $158 / 164$ \\
\hline M. Gordon’ & $185 / 195$ & $270 / 312$ & $164 / 170$ & 184 & $161 / 164$ \\
\hline Middletown' & $183 / 193$ & $270 / 321$ & 170 & 184 & $158 / 161$ \\
\hline 'Mitchell' & $-1-$ & $266 / 321$ & $158 / 172$ & 184 & $158 / 167$ \\
\hline $\mathrm{NC}-1$ & $185 / 193$ & 266 & $158 / 162$ & 184 & $158 / 161$ \\
\hline Overleese' & $185 / 189$ & 264 & $158 / 164$ & $175 / 184$ & 158 \\
\hline PA-Golden\#1' & $191 / 193$ & $336 / 343$ & $172 / 176$ & 184 & $158 / 164$ \\
\hline PA-Golden\#3' & $189 / 191$ & $336 / 343$ & $158 / 172$ & 184 & $161 / 170$ \\
\hline PA-Golden\#4' & $175 / 183$ & $319 / 326$ & 164 & 184 & $158 / 161$ \\
\hline Potomac' & $183 / 191$ & $264 / 324$ & 170 & 184 & $158 / 164$ \\
\hline 'Prolific' & $189 / 191$ & $309 / 323$ & $158 / 162$ & 184 & 158 \\
\hline 'Rappahannock' & $183 / 191$ & 266 & 166 & 184 & $164 / 170$ \\
\hline 'Rebecca's Gold' & $185 / 193$ & 266 & $158 / 162$ & 184 & $158 / 161$ \\
\hline Shenandoah' & $185 / 187$ & $264 / 274$ & $162 / 164$ & 184 & $158 / 164$ \\
\hline 'Sue' & $175 / 189$ & $266 / 329$ & $166 / 180$ & 184 & $161 / 164$ \\
\hline Sunflower' & 187 & $274 / 341$ & $162 / 180$ & $175 / 184$ & 164 \\
\hline Susquehanna' & $189 / 191$ & $264 / 270$ & 162 & 184 & $158 / 167$ \\
\hline Sweet Alice' & $175 / 183$ & $260 / 324$ & $166 / 182$ & 184 & $144 / 164$ \\
\hline 'Taylor' & $183 / 185$ & $268 / 322$ & $173 / 193$ & 184 & $167 / 170$ \\
\hline 'Taytwo' & $175 / 185$ & $252 / 290$ & 158 & 184 & $164 / 176$ \\
\hline Wabash' & 183 & $266 / 324$ & $170 / 172$ & 184 & $158 / 170$ \\
\hline Wells' & $175 / 191$ & $276 / 290$ & 177 & 184 & $161 / 164$ \\
\hline Wilson' & $183 / 185$ & $268 / 321$ & $173 / 193$ & 184 & $167 / 170$ \\
\hline 'Zimmerman' & $191 / 195$ & $303 / 324$ & $164 / 177$ & 184 & 158 \\
\hline
\end{tabular}

II), 'Wabash' (Group III), 'Wells' (Group IV), and 'Overleese' (Group V).

The 'Overleese' group contains 'Davis', 'Sunflower', and four genotypes thought to be seedlings of 'Overleese'. 'IXL' and 'NC-1', hybrids between 'Overleese' and 'Davis', clustered with their parents. 'Shenandoah' and 1-68 are seedlings of 'Overleese' and were placed in the same group. Selection 123 , thought to be a seedling of 'Taylor', was unexpectedly placed in this group. Selection 8-20, thought to be a seedling of 'Sunflower', was assigned to the 'Susquehanna' group. 'PAGolden \#1' and 'PA-Golden \#3' were placed in the 'Susquehanna' group, while 'PA-Golden \#4' was placed in the 'Wabash' group. These three selections originated from the remaining trees in the collection of G.A. Zimmerman, and different genetic backgrounds were expected. 


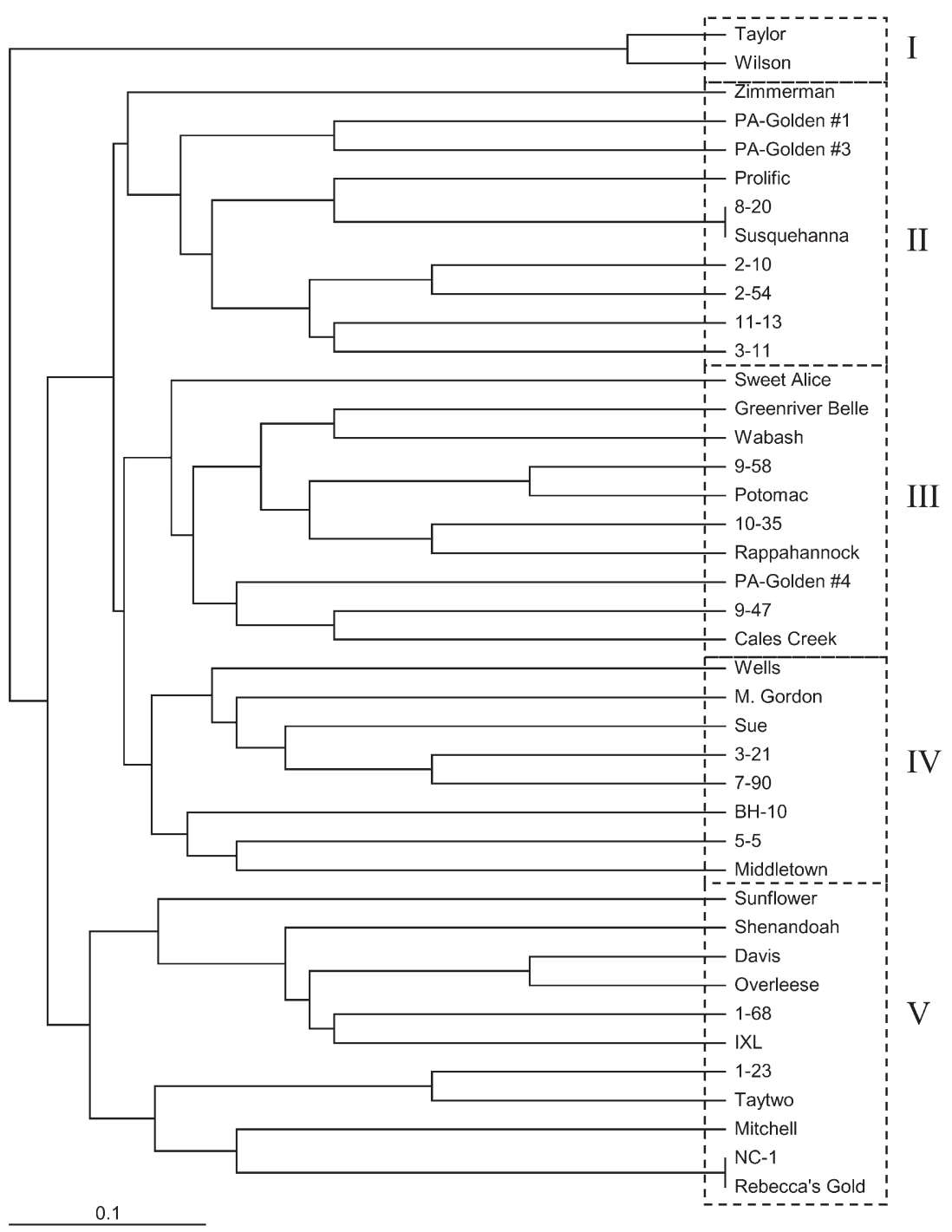

Fig. 1. UPGMA dendrogram of 41 pawpaw genotypes based on five microsatellite loci and shared allele distance. Genotypes are grouped by 'Taylor' and 'Wilson' (Group I), 'Susquehanna' (Group II), 'Wabash' (Group III), 'Wells' (Group IV), and 'Overleese' (Group V).

\section{Discussion}

This is the first report of the development of SSR loci for pawpaw. These primer pairs can now be used to assess genetic diversity in pawpaw and provide reproducible fingerprints for cultivar identification. These primers may also be useful for other Asimina species. We attempted to amplify DNA of cherimoya at the five loci, but obtained no PCR products (data not shown). Cherimoya is in the same family as pawpaw, but SSR markers are not always transferable among genera.

The SSR fingerprinting of the 41 pawpaw accessions identified 39 unique genotypes. Only two pairs of accessions could not be distinguished. The dendrogram of pawpaw genotypes constructed from SSR marker data are similar in many respects to those constructed using other types of markers. Markers used in previous studies include RAPDs (Huang et al., 2003), AFLPs (Wang et al., 2005), and ISSRs (Pomper et al., 2003). All of these studies have shown 'Taylor' and 'Wilson' to be similar. Using RAPD markers, Huang et al. (2003) placed 'Overleese' and its seedlings 'Shenandoah' and
1-68 in the same group, as did we based on SSR markers. Using AFLP markers, Wang et al. (2005) showed that 'Taytwo' and 1-23 were closely related, which is consistent with our results. We could not distinguish between 'Rebecca's Gold' and 'NC-1' using SSR markers. Pomper et al. (2003), using ISSR markers, could not distinguish between these two cultivars. However, Huang et al. (2003) reported differences in RAPD markers. 'Sunflower' was assigned to different groups in these studies. Some discrepancies are to be expected, as different marker systems sample different genomic regions.

A high level of genetic diversity was detected in the pawpaw genotypes. The high average number of alleles per locus (12.0) is comparable to that in other outcrossing woody perennial fruit and nut crop species such as 13.3 alleles per locus reported for hazelnut (Bassil et al., 2005), 9.5 per locus for avocado [Persea americana M. (Lavi et al., 1994)], 10.7 for sour cherry (Cantini et al., 2001), 12.1 for apple (Hokanson et al., 1998), and 9.1 for pear (Sisko et al., 2009). Tree species with lower reported average alleles per locus include olive (Olea europaea L.) with 5.5 (Noormohammadi et al., 2007), peach at 2.2 (Ahmad et al., 2004), and avocado in Ghana at 4.4 (Acheampong et al., 2008). Microsatellite marker loci have been used to study two species of Annona L., which are relatives of pawpaw. In Annona crassiflora Mart., an undomesticated species native to Brazil, Pereira et al. (2008) used 10 SSR loci and reported averages of 19.3 alleles per locus, $\mathrm{H}_{\mathrm{e}}=0.91$ and $\mathrm{H}_{\mathrm{o}}=0.81$. In cherimoya, Escribano et al. (2008) reported averages of only 4.9 alleles per locus, $\mathrm{H}_{\mathrm{e}}=0.53$ and $\mathrm{H}_{\mathrm{o}}=0.44$. If locus Pp$\mathrm{C} 104$ is set aside, the values for pawpaw are similar to those for $A$. crassiflora.

$\mathrm{H}_{\mathrm{e}}(0.70)$ and PIC (0.68) indicated high levels of genetic diversity among the pawpaw genotypes examined. Hazelnut is a perennial tree species that also has high genetic diversity in commercially available cultivars. Using SSR markers, Bassil et al. (2005) reported high $\mathrm{H}_{\mathrm{e}}$ and PIC value for hazelnut cultivars of 0.68 and 0.64 , respectively. Pereira et al. (2008) reported a $\mathrm{H}_{\mathrm{e}}$ of 0.91 for undomesticated trees of $A$. crassiflora. Escribano et al. (2008) reported a $\mathrm{H}_{\mathrm{e}}$ of 0.53 and $\mathrm{H}_{\mathrm{o}}$ of 0.44 for cherimoya. The pawpaw cultivars and advanced selections appear to display a much larger genetic base than currently reported for cherimoya and positively support continued efforts toward the further domestication of pawpaw.

This study provides additional evidence that high levels of genetic diversity exist in A. triloba (Huang et al., 1997, 1998, 2000; Pomper et al., 2003; Wang et al., 2005), which is consistent with frequent seed reproduction and adaptation of different environments. Pomper et al. (2009b) reported that at least half of the pawpaw patches examined with ISSR markers had at least two genotypes. The development of additional polymorphic SSR markers would facilitate future studies. 
In conclusion, six pawpaw microsatellite loci were identified and SSR primer sets developed to fingerprint and assess genetic diversity in pawpaw cultivars and advanced selections from the PPF breeding program. High $\mathrm{H}_{\mathrm{e}}$ and PIC values indicated high levels of genetic diversity among the genotypes examined, which positively supports the continued efforts toward the further domestication of pawpaw. Microsatellite fingerprints will provide a reproducible means of identifying pawpaw cultivars and for managing germplasm in nurseries and the KSU repository collection.

\section{Literature Cited}

Acheampong, A.K., R. Akromah, F.A. Ofori, J.F. Takrama, D. Saada, I. Bitton, and U. Lavi. 2008. Genetic characterization of Ghanaian avocados using microsatellite markers. J. Amer. Soc. Hort. Sci. 133:801-809.

Ahmad, R., D. Potter, and S.M. Southwick. 2004. Genotyping of peach and nectarine cultivars with SSR and SRAP molecular markers. J. Amer. Soc. Hort. Sci. 129:204-210.

Aranzana, M.J., J. Carbó, and P. Arús. 2002. Microsatellite variability in peach [Prunus persica (L.) Batsch]: Cultivar identification, marker mutation, pedigree inferences, and population structure. Theor. Appl. Genet. 106:1341-1352.

Bassil, N.V., R. Botta, and S.A. Mehlenbacher. 2005. Microsatellite markers in hazelnut: Isolation, characterization, and cross-species amplification. J. Amer. Soc. Hort. Sci. 130:543-549.

Boches, P., N.V. Bassil, and L. Rowland. 2006. Genetic diversity in the highbush blueberry evaluated with microsatellite markers. J. Amer. Soc. Hort. Sci. 131:674-686.

Botstein, D., R.L. White, M. Skolnick, and R.W. Davis. 1980. Construction of a genetic linkage map in man using restriction fragment length polymorphisms. Amer. J. Hum. Genet. 32:314-331. Bowcock, A.M., A. Ruis-Linares, J. Tomfohrde, E. Minch, J.R. Kidd, and L.L. Cavalli-Sforza. 1994. High resolution of human evolutionary trees from polymorphic microsatellites. Nature 368:455-457.

Bowden, W.M. 1948. Chromosome numbers in the Annonaceae. Amer. J. Bot. 35:377-381.

Callaway, M.B. 1990. The pawpaw (Asimina triloba). Kentucky State Univ. Publ. CRS-HORT1-901T.

Callaway, M.B. 1993. Pawpaw (Asimina triloba): A "tropical" fruit for temperate climates, p. 505-515. In: J. Janick and J.E. Simon (eds.). New crops. Wiley, New York.

Cantini, C., A.F. Iezzoni, W.F. Lamboy, M. Boritzki, and D. Struss. 2001. DNA fingerprinting of tetraploid cherry germplasm using simple sequence repeats. J. Amer. Soc. Hort. Sci. 126:205-209.

Cypher, B.L. and E.A. Cypher. 1999. Germination rates of tree seeds ingested by coyotes and raccoons. Amer. Midl. Nat. 142:71-76.

Darrow, G.M. 1975. Minor temperate fruits, p. 276-277. In: J. Janick and J.N. Moore (eds.). Advances in fruit breeding. Purdue Univ. Press, West Lafayette, IN.

Duffrin, M.W. and K.W. Pomper. 2006. Development of flavor descriptors for pawpaw fruit puree: A step toward the establishment of a native tree fruit industry. Fam. Consum. Sci. Res. J. 35:118-130.

Escribano, P., M.A. Viruel, and J.I. Hormaza. 2008. Development of 52 new polymorphic SSR markers from cherimoya (Annona cherimola Mill.): Transferability to related taxa and selection of a reduced set for DNA fingerprinting and diversity studies. Mol. Ecol. Resources 8:317-321.

Faegri, K. and L. van der Piji. 1971. The principles of pollination ecology. Pergammon, New York.

Geneve, R.L., K.W. Pomper, S.T. Kester, J.N. Egilla, C.L.H. Finneseth, S.B. Crabtree, and D.R. Layne. 2003. Propagation of pawpaw: A review. HortTechnology 13:428-433.

Hamrick, J.L. and M.J.W. Godt. 1989. Allozyme diversity in plant species, p. 43-63. In: A.H.D. Brown, M.T. Clegg, A.L. Kahler, and B.S. Weir (eds.). Plant population genetics, breeding and genetic resources. Sinauer Associates, Sunderland, MA.
Hokanson, S.C., A.K. Szewc-McFadden, W.F. Lamboy, and J.R. McFerson. 1998. Microsatellite (SSR) markers reveal genetic identities, genetic diversity, and relationships in a Malus $\times$ domestica Borkh. core subset collection. Theor. Appl. Genet. 97: 671-683.

Hokanson, S.C., W.F. Lamboy, A.K. Szewc-McFadden, and J.R. McFerson. 2001. Microsatellite (SSR) variation in a collection of Malus (apple) species and hybrids. Euphytica 118:281-294.

Huang, H., D.R. Layne, and T.L. Kubisiak. 2000. RAPD inheritance and diversity in pawpaw (Asimina triloba). J. Amer. Soc. Hort. Sci. 125:454-459.

Huang, H., D.R. Layne, and T.L. Kubisiak. 2003. Molecular characterization of cultivated pawpaw (Asimina triloba) using RAPD markers. J. Amer. Soc. Hort. Sci. 128:85-93.

Huang, H., D.R. Layne, and R.N. Peterson. 1997. Using isozyme polymorphisms for identifying and assessing genetic variation in cultivated pawpaw [Asimina triloba (L.) Dunal]. J. Amer. Soc. Hort. Sci. 122:504-511.

Huang, H., D.R. Layne, and D.E. Riemenschneider. 1998. Genetic diversity and geographic differentiation in pawpaw [Asimina triloba (L.) Dunal] populations from nine states as revealed by allozyme analysis. J. Amer. Soc. Hort. Sci. 123:635-641.

Kijas, J.M.H., J.C.S. Fowler, and M.R. Thomas. 1995. An evaluation of sequence tagged microsatellite site markers for genetic analysis within Citrus and related species. Genome 38:349-355.

Kral, R. 1960. A revision of Asimina and Deeringothamnus (Annonaceae). Brittonia 12:233-278.

Lavi, U., M. Akkaya, A. Bhagwat, E. Lahav, and P.B. Cregan. 1994. Methodology of generation and characteristics of simple sequence repeat DNA markers in avocado (Persea americana M.). Euphytica 80:171-177.

Layne, D.R. 1996. The pawpaw [Asimina triloba (L.) Dunal]: A new fruit crop for Kentucky and the United States. HortScience 31:777784.

Liu, K. and S.V. Muse. 2005. PowerMarker: Integrated analysis environment for genetic marker data. Bioinformatics 21:2128-2129.

McLaughlin, J.L. 2008. Pawpaw and cancer: Annonaceous acetogenins from discovery to commercial products. J. Nat. Prod. 71:13111321.

Noormohammadi, Z., M. Hosseini-Mazinani, I. Trujillo, L. Rallo, A. Belaj, and M. Sadeghizadeh. 2007. Identification and classification of main Iranian olive cultivars using microsatellite markers. HortScience 42:1545-1550.

Pereira, M.F., L.F. Bandeira, A.J.V. Blanco, A.Y. Ciampi, and A.S.G. Coelho. 2008. Development of microsatellite markers in Annona crassiflora Mart., a Brazilian cerrado fruit tree species. Mol. Ecol. Resources 8:1329-1331.

Peterson, R.N. 1986. Research on the pawpaw (Asimina triloba) at the University of Maryland. 77th Annu. Rpt. Northern Nut Growers Assn. 77:73-78.

Peterson, R.N. 1991. Pawpaw (Asimina). Genetic resources of temperate fruit and nut crops. Acta Hort. 290:567-600.

Peterson, R.N. 2003. Pawpaw variety development: A history and future prospects. HortTechology 13:449-454.

Peterson, R.N., J.P. Cherry, and J.G. Simmons. 1982. Composition of pawpaw (Asimina triloba) fruit. Annu. Rpt. Northern Nut Growers Assn. 73:97-107.

Pomper, K.W., S.B. Crabtree, S.P. Brown, S.C. Jones, T.M. Bonney, and D.R. Layne. 2003. Assessment of genetic diversity of pawpaw varieties with inter-simple sequence repeat markers. J. Amer. Soc. Hort. Sci. 128:521-525.

Pomper, K.W., S.B. Crabtree, D.R. Layne, and R.N. Peterson. 2008a. Flowering and fruiting characteristics of eight pawpaw (Asimina triloba) selections in Kentucky. J. Amer. Pomol. Soc. 62:89-97.

Pomper, K.W., S.B. Crabtree, D.R. Layne, R.N. Peterson, J. Masabni, and D. Wolfe. 2008b. The Kentucky pawpaw regional variety trial. J. Amer. Pomol. Soc. 62:58-69. 
Pomper, K.W., S.B. Crabtree, and J.D. Lowe. 2009a. Pawpaw cultivar list and fruit photographs. 26 Feb. 2010. $<$ http://www.pawpaw.kysu. edu/pawpaw/cvsrc98.htm>.

Pomper, K.W., S.C. Jones, and L. Barnes. 2000. The influence of low temperature storage on the germination rate of pawpaw [Asimina triloba (L.) Dunal] seed. Annu. Rpt. Northern Nut Growers Assn. 91:20-27.

Pomper, K.W. and D.R. Layne. 2005. The North American pawpaw: Botany and horticulture. Hort. Rev. (Amer. Soc. Hort. Sci.) 31:351384.

Pomper, K.W., J.D. Lowe, L. Lu, S.B. Crabtree, and L.A. Collins. 2009b. Clonality of pawpaw (Asimina triloba) patches in Kentucky. J. Kentucky Acad. Sci. 70:3-11.

Rogstad, S.H., K. Wolff, and B.A. Schaal. 1991. Geographical variation in Asimina triloba Dunal (Annonaceae) revealed by the M13 DNA fingerprinting probe. Amer. J. Bot. 78:1391-1396.

Shiota, H. 1991. Volatile components of pawpaw fruit (Asimina triloba Dunal). J. Agr. Food Chem. 39:1631-1635.

Sisko, M., B. Javornik, A. Siftar, and A. Ivancic. 2009. Genetic relationships among Slovenian pears assessed by molecular markers. J. Amer. Soc. Hort. Sci. 134:97-108.
Templeton, S.B., M. Marlette, K.W. Pomper, and S.C. Jones. 2003. Favorable taste ratings for several pawpaw products. HortTechnology 13:445-448.

Wang, Y., G.L. Reighard, D.R. Layne, A.G. Abbott, and H. Huang. 2005. Inheritance of AFLP markers and their use for genetic diversity analysis in wild and domesticated pawpaw [Asimina triloba (L.) Dunal]. J. Amer. Soc. Hort. Sci. 130:561-568.

Willson, M.F. and D.W. Schemske. 1980. Pollinator limitation, fruit production, and floral display in pawpaw (Asimina triloba). Bull. Torrey Bot. Club 107:401-408.

Wünsch, A. and J.J. Hormaza. 2002. Cultivar identification and genetic fingerprinting of temperate fruit tree species using DNA markers. Euphytica 125:59-67.

Yamamoto, T., T. Kimura, Y. Sawamura, K. Kotobuki, Y. Ban, T. Hayashi, and N. Matsuta. 2001. SSRs isolated from apple can identify polymorphism and genetic diversity in pear. Theor. Appl. Genet. 102:865-870.

Young, D.R. and J.B. Yavitt. 1987. Differences in leaf structure, chlorophyll, and nutrients for the understory tree Asimina triloba. Amer. J. Bot. 74:1487-1491. 